ORIGINAL ARTICLE

\title{
Correlation between Heavy School Bags and Upper Limb Disabilities among School Going Children
}

\author{
UMER ILYAS ${ }^{1}$, SHOAIB WAQAS ${ }^{2}$, ZAHID MEHMOOD BHATTI ${ }^{3}$, WAJIDA PERVEEN ${ }^{4}$, MISBAH AMANAT ALI ${ }^{5}$ \\ ${ }^{1}$ Senior Lecturer, PSRD College of Rehabilitation Sciences, Lahore. \\ ${ }^{2}$ Associate Professor at Lahore college of Physiotherapy, LMDC, Lahore. \\ ${ }^{3}$ Associate Professor/ HOD at Bakhtawar Amin College of Rehabilitation Sciences, Multan. \\ ${ }^{4}$ Assistant Professor/ HOD/ Programme Director DPT, Sialkot College of Physical Therapy, Amin Welfare \& Teaching Hospital, Sialkot. \\ ${ }^{4}$ Assistant Professor Sialkot College of Physical Therapy, Amin Welfare \& Teaching Hospital, Sialkot. \\ Correspondence to Shoaib Waqas Email: shoaib.waqas@lmdc.edu.pk, Contact: 0092-302-45572109
}

\begin{abstract}
Aim: To find out correlation between heavy school bags and upper limb disabilities among school going children. Methods: This descriptive cross-sectional survey, using non-probability convenience sampling, was conducted on 396 students of 11 to 15 years after ethical approval in 6 months. Height (in $\mathrm{cm}$ ) and weight (in Kg) were noted and BMI was calculated. Students with the normal BMI were included in the study. Weigh of the students were recorded with their shoes off while the weight of the bags was calculated with all the stationary included. Quick DASH scale score was calculated and correlated with the weight of the bag by applying Chi-Square test.

Results: The mean age of the participants was13.49 \pm 1.12 years. The mean weight of the school bag was $6.10 \pm 2.1 \mathrm{Kgs}$ while the students were carrying more than one-quarter of their body weight. The disability calculated from the quick DASH scale was as high as 40\%. Chi-square showed a significant correlation between the upper limb disabilities and the weight of the bag.

Conclusion: The study showed that there is a significant correlation that the use of heavy school bags can cause upper limb disabilities in children.

Keywords: Heavy School Bags, Upper Limb Disabilities, Children, Disabilities of Arm Shoulder and Hand
\end{abstract}

\section{INTRODUCTION}

Students could be carrying school bags ranging from $10 \%$ to as heavy as $25 \%$ of their body weight ${ }^{1}$ and if the school bag is $15 \%$ of student's body weight it changes all the postural mechanics of the student ${ }^{2}$ carrying $15 \%$ of their body weight, the child body can adapt to these biomechanical stress inflicted on them which leads to the increase in musculoskeletal injury risk ${ }^{1}$.

The weight of the school bag is strongly correlated with the occurrence of upper limb musculoskeletal discomforts ${ }^{3}$ not only in the spine it also changes the head mechanics ${ }^{4}$ in which the forward head position is one of the commonest which elongates the cervical flexors and shorten the cervical extensors ${ }^{5}$. As students carry school bags on daily basis there is no defined weight guideline for the weight of the school bag ${ }^{6}$. The students carry their books, stationery items, and other study-related material in the schoolbags as it is the easiest and most convenient way of carrying the load on their way to school ${ }^{7}$.

Children age 10 to 19 years undergo rapid growth and maturation of soft tissues and the musculoskeletal system. Any undue stress or external force on their body can alter their posture and alignment of the body. In a study conducted in 2019 concluded while carrying a school bag $18 \%$ of their body weight decreases the craniovertebral angle by $24.51^{\circ}$ as compared to $40.62^{\circ}$ while standing with no school bag while the angle decreases when a student was moving which indicates the adaptation of forward head posture and sagittal shoulder posture was twice the normal values after dynamic activity. These values indicate towards the more rounded shoulders than normal while

Received on 07-04-2021

Accepted on 27-08-2021 their daily compute to or in the school environment ${ }^{4}$.

In Kuwait, a study was conducted on high school children age 14 to 19 years to make a relation between school bags and lower back pain. It was estimated that $70 \%$ of the students have experienced back pain at least once at some point in their life. Whereas $49 \%$ and $31 \%$ experienced it within 6 months and one month back respectively ${ }^{8}$.

The researchers were not able to find out a single study that can measure the correlation between heavy school bags and upper limb disabilities among schoolgoing children in Pakistan, and it's a very challenging topic to be researched both in the context of the researcher and students.

The rationale of the current study is to find out the correlation between heavy school bags and upper limb disabilities.

\section{METHODS}

This descriptive cross-sectional survey, using nonprobability convenience sampling, was conducted in six months after ethical approval. The sample size is estimated as 396, using google calculator ${ }^{9}$. Permission from IRB and parents was achieved to include the students in the study. Data was collected from Umer Public School Sialkot \& St. Mary's high school Sialkot. Height and weight were noted and BMI was calculated. Students of the classes $\left(6^{\text {th }}, 7\right.$ th, $\left.8^{\text {th }}\right)$ Age 11 to 15 years with a BMl of 18.5 to $24.9 \mathrm{Kg} / \mathrm{m}^{2}$ were included while Any participant with visible deformity, Vitamin D deficiency, Metabolic disorders or Type I diabetics were excluded from the study.

Weigh of the students were recorded with their shoes off while the weight of the bags was calculated with all the stationary included. Quick DASH scale was used to collect 
data. Chi-Square test was used to find correlations and $P$ value less than 0.05 was considered statistically significant.

\section{RESULTS}

The mean age of the students was $13.49 \pm 1.1$ years ranging from 11-15 years. But most of the students were lying in the age group of 13 years. Majority of the students were females. The mean weight of the students was $45 \mathrm{Kgs} \pm 4.34 \mathrm{SD}$ ranging from $28-80 \mathrm{Kgs}$. The average height of the students was 1.5 meters \pm SD 0.13 ranging from 1.2-1.81 meters. The average mean of the student $\mathrm{BMI}$ was $20.04 \mathrm{Kgs} / \mathrm{m}^{2} \pm 1.85$. Ranging from $18.42-24.99 \mathrm{Kgs} / \mathrm{m}^{2}$. The trend shows that most of the students are in the lower range of normal BMI. The weight of the bag was $6.1 \mathrm{Kgs} \pm 2.1 \mathrm{SD}$ with a range of 2 to $15 \mathrm{Kgs}$.

The average weight of the bag relative to the body weight was $14.25 \% \pm 4.5 \%$ SD. Out of 396 students, 355 were carrying more than $10 \%$ of their body weight. The mean disability index of the students was $14.21 \% \pm 8.7 \mathrm{SD}$ and reaching as high as $40 \%$. Nearly half of the students experienced different levels of pain in the arm shoulder or arm and those students who experienced pain around $4 \%$ experienced severe pain. $48.7 \%$ of the students experienced difficulty in sleeping and of these $73.5 \%$ had mild, $12 \%$ had moderate, $11.3 \%$ had severe difficulty in sleeping and $0.5 \%$ of the 396 students were unable to sleep in the past week due to the arm shoulder or hand pain. Chi-square was applied to the data and it showed a significant correlation between the upper limb disabilities and the weight of the bag (Table 1).

Correlation between the total score in the DASH scale and the weight of the bag was also observed as the significance is less than 0.05 . The value is less than 0.05 which shows a correlation between the weight of the school bag and upper limb disability.

Table 1: Correlation between DASH score and weight of the bag Chi-Square Tests

\begin{tabular}{|l|c|c|c|}
\hline \multirow{2}{*}{ Statistics } & \multicolumn{3}{|c|}{ Values } \\
\cline { 2 - 4 } & Value & df & $\begin{array}{c}\text { Asymptotic } \\
\text { Significance } \\
\text { (2-sided) }\end{array}$ \\
\hline Pearson Chi-Square & 372.28 & 323 & .03 \\
\hline Likelihood Ratio & 288.40 & 323 & .91 \\
\hline Linear-by-Linear Association & .95 & 1 & .32 \\
\hline N of Valid Cases & 396 & & \\
\hline
\end{tabular}

Table 2: Correlation between the weight of the school bag and UL disability

\begin{tabular}{|l|c|c|}
\hline & Weight & Disability index \\
\hline Chi-Square & 385.81 & 258.54 \\
\hline Df & 19 & 17 \\
\hline Asymp. Sig. & 0.00 & 0.00 \\
\hline
\end{tabular}

\section{DISCUSSION}

In our study An association was observed between DASH score and weight of the bag and age while no association was found between height, gender, and BMI. The average weight of the school bag ranges from $10 \%$ to $25 \%$ of the body weight in our research the weight carried by the student was more than $33 \%$ which was much higher than the study conducted in 2018 .

The average weight of the school bag was $15 \%$ is enough to change the mechanics of the body and as in our study the students were carrying around $33 \%$ of their body weight and the correlation of disability index and weight of the bag relative to the weigh of the student was also observed $^{2}$.

In 2013 a study on the secondary students suggested that the female students are more prone to MSK issues but our study suggested that there is no correlation between gender and upper limb disabilities ${ }^{10}$.

However, as the child progresses through school and pursues higher education the musculoskeletal problem increases. This research done in 2016 correlates with our study ${ }^{11}$.

The research reported in 2014 suggested that students experienced a sharp pain in the shoulder which radiates into the arm and our research also suggested the nearly half of the students had shoulder arm or hand pain in the past week ${ }^{12}$.

\section{CONCLUSION}

There is an increased prevalence of incapacities in school going children because of the weight of their school bags. Majority of the students had some degree of disability in their UL related to the heavy school bag. The weight of the bag also affects the sleep of a child.

\section{Conflict of interest: Nil}

\section{REFERENCES}

1. Perrone M, Orr R, Hing W, Milne N, Pope R. The impact of backpack loads on school children: A critical narrative review. International journal of environmental research and public health. 2018;15(11):2529.

2. Ramprasad M, Alias J, Raghuveer A. Effect of backpack weight on postural angles in preadolescent children. Indian pediatrics. 2010;47(7):575-80.

3. Shamsoddini A, Hollisaz M, Hafezi R. Backpack weight and musculoskeletal symptoms in secondary school students, Tehran, Iran. Iranian journal of public health. 2010;39(4):120.

4. Vaghela NP, Parekh SK, Padsala D, Patel D. Effect of backpack loading on cervical and sagittal shoulder posture in standing and after dynamic activity in school going children. Journal of Family Medicine and Primary Care. 2019;8(3):1076.

5. Kendall FP, McCreary EK, Provance PG, Rodgers M, Romani WA. Muscles, testing and function: with posture and pain: Williams \& Wilkins Baltimore, MD; 1993

6. Dockrell S, Simms C, Blake C. Schoolbag weight limit: can it be defined? Journal of school health. 2013;83(5):368-77.

7. Knapik J, Harman E, Reynolds K. Load carriage using packs: a review of physiological, biomechanical and medical aspects. Applied ergonomics. 1996;27(3):207-16.

8. Akbar F, AlBesharah M, Al-Baghli J, Bulbul F, Mohammad D, Qadoura B, et al. Prevalence of low Back pain among adolescents in relation to the weight of school bags. BMC musculoskeletal disorders. 2019;20(1):37.

9. Haselgrove C, Straker L, Smith A, O'Sullivan P, Perry M, Sloan N. Perceived school bag load, duration of carriage, and method of transport to school are associated with spinal pain in adolescents: an observational study. Australian Journal of Physiotherapy. 2008;54(3):193-200.

10. Saleh AG, Mohammed AH. Effect of Backpacks Carried by Secondary School Students in Tanta City on the Musculoskeletal System. Bull Fac Ph Th Cairo Univ. 2013;18(2):69.

11. Aprile I, Di Stasio E, Vincenzi MT, Arezzo MF, De Santis F, Mosca R, et al. The relationship between back pain and schoolbag use: a cross-sectional study of 5,318 Italian students. The Spine Journal. 2016;16(6):748-55.

12. Rai A, Agarwal S. Effect of Postural Discomfort on School Going Children Carrying Heavy Backpacks. International Journal of Science and Research (IJSR). 2014;3(12):2482-4. 